\title{
A história de uma Ialorixá sob a ótica de um pastor canadense: \\ Robert McAlister e as Religiões Afro-Brasileiras
}

\section{The History of a Yalorixá from the Perspective of a Canadian Pastor: Robert McAlister and Afro-Brazilian Religions}

\author{
Artur Cesar Isaia ${ }^{1}$ \\ Elizete da Silva ${ }^{2}$
}

Submetido em 18 de novembro e aprovado em 2 de dezembro de 2019.

\begin{abstract}
Resumo: Este texto trata da narrativa em torno da vida de uma Ialorixá convertida do Candomblé a uma Igreja Pentecosal chamada Cruzada Nova Vida. Esta Igreja foi fundada pelo pastor canadense Robert McAlister, precursor do uso de práticas proselitistas midiáticas no Brasil. A conversão da Ialorixá aparece como a vitória cristã sobre o que McAlister apresenta como a ação do demônio na sociedade brasileira: o Candomblé e a Umbanda. Além desses, o Espiritismo e o Catolicismo aparecem, igualmente, dominados pelo mal ancestral. A sociedade brasileira aparece na narrativa, portanto, como um território de missão, o qual era necessário converter para Cristo. Em tom apologético, McAlister desenvolve os marcadores das narrativas cristãs de conversão. Esses marcadores passam pelo repúdio às antigas práticas e a submissão à mensagem cristã.
\end{abstract}

Palavras-Chave: Religiões Afro-Brasileiras. Pentecostalismo. Candomblé.

Abstract: This text deals with the narrative surrounding the life of a Yalorixá converted from Candomblé to a Pentecosal Church called the New Life Crusade. This church was founded by Canadian pastor Robert McAlister, a precursor to the use of proselytizing media practices in Brazil. The conversion of the Ialorixá appears as the Christian victory over what McAlister presents as the devil's action in Brazilian society: Candomblé and Umbanda. Besides these, Spiritism and Catholicism are equally dominated by the ancestral evil. Brazilian society appears in the narrative, therefore, as a mission territory, which was necessary to convert to Christ. In an apologetic tone, McAlister develops the markers of Christian conversion narratives. These markers include repudiation of ancient practices and submission to the Christian message.

Key-Words: Afro-Brazilian Religions. Pentecostalism. Candomblé. 


\section{Introdução}

Nos anos 1960, o pastor Robert McAlister publicou a obra Mãe de Santo, a qual pretendia dar publicidade às experiências religiosas de uma praticante e dirigente do Candomblé e da Umbanda: Georgina Aragão dos Santos Franco. Esta baiana, bisneta de africanos, integrava uma linhagem de matriarcas do Candomblé, tendo sua bisavó sido Ialorixá na Bahia. O livro, em tom apologético, narra a conversão de Georgina à Cruzada Nova Vida, fundada por McAlister, o abandono das práticas do Candomblé e da Umbanda e a transformação na sua vida a partir do momento em que "se livra" das mesmas, passando a nortear a sua vida pela Bíblia.

O Pastor Robert McAlister, foi um missionário canadense, nascido em 1933 em Ontário e falecido em 1993 no Rio de Janeiro. No Brasil, McAlister fundou a Igreja Pentecostal Nova Vida, comunidade religiosa que inaugurou, já nos anos 1960, práticas e métodos proselitistas midiáticos, que se transformariam posteriormente em características relevantes para o desenvolvimento dos grupos neopentecostais, a exemplo da Igreja Universal do Reino de Deus.

A vida de Georgina, escrita por McAlister é aqui enfocada atendo-nos ao seu caráter monumental (LE GOFF, 1990), ou seja, como um documento construído segundo um repertório de intencionalidades historicamente compreensíveis.

\section{A mensagem pentecostal: do Canadá ao Brasil}

O crescimento exponencial de grupos de origem pentecostal no Brasil tem despertado o interesse de sociólogos, antropólogos e historiadores, dispostos a analisar os fatores que induzem o crescimento e o potencial político de uma vertente do Protestantismo estabelecida no Brasil nas primeiras décadas do século XX. Esta vertente enfatiza os dons do Espírito Santo, a cura e a glossolalia, isto é, o dom de falar línguas conhecidas e espirituais, como uma prova de santificação dos fiéis, bem como expressão corporal e gestual marcados por palmas e clamores de glórias e aleluias.

Nesta exegese bíblica, as origens do Pentecostalismo podem ser traçadas no Novo Testamento, quando no dia de Pentecostes os cristãos da Igreja Primitiva e Judeus da diáspora, ouviam na sua própria língua a mensagem dos discípulos, conforme o relato 
bíblico de Atos dos Apóstolos, capítulo 2. Para alguns autores podem ser identificados como os iluminados da Reforma Protestante, Anabatistas e Quakers, que tinham frêmitos, êxtases espirituais e tremiam ao ser possuídos pelo Espírito Santo. Ou, ainda, como grupos remanescentes dos avivamentos religiosos ocorridos no seio do protestantismo europeu e estadunidense dos séculos XVII, XVIII e XIX, que buscavam fugir da racionalidade protestante tradicional para uma religiosidade do coração, conforme pensava John Wesley.

O movimento pentecostal recente surgiu nos EUA, herdeiro dos avivamentos espirituais anteriores, do Metodismo e de doutrinas batistas. As origens foram as fervorosas reuniões da Rua Azusa, Los Angeles, em 1906, que ocorriam com grande afluência de afrodescendentes e pessoas vinculadas às classes trabalhadoras, como o garçom negro Seymour, considerado um pioneiro pentecostal. Convém ressaltar que as doutrinas pentecostais chegaram ao Brasil a partir de 1910 e foram trazidas por imigrantes europeus brancos, italianos ${ }^{3}$, suecos ${ }^{4}$, não por afrodescendentes. A Igreja Assembléia de Deus foi fundada em 1911, em Belém do Pará por pioneiros suecos, já os canadenses, a exemplo da família McAlister, chegaram posteriormente no contexto da expansão do Pentecostalismo no mundo.

No Canadá, o fervor espiritual, medido em práticas devocionais com altos decibéis de emoção, também atingiu Igrejas Batistas e Metodistas, ainda nos primórdios do século XX. Alguns autores identificam o movimento pentecostal nas comunidades protestantes, ocorrendo concomitantemente nos EUA, Canadá e Austrália. Em 1910, já existiam congregações pentecostais nas principais cidades canadenses, a exemplo de Ontário, Toronto, Winnipeg, que desenvolveram fortes laços com o Pentecostalismo estadunidense.

O missionário Robert McAlister, conhecido no Brasil como Pastor ou Bispo Roberto, pertencia a uma família metodista canadense, com vários pastores e líderes evangélicos. Seu pai Walter E. McAlister foi superintendente da Conferência Geral Pentecostal do Canadá, sediada em Ontário e recebeu o batismo com o Espírito Santo na rua Azusa. Com uma forte visão proselitista, os pentecostais canadenses criaram o Fundo de Missões Mundiais e o jovem Robert McAlister engajou-se no trabalho missionário em Hong Kong, onde também organizou uma Igreja Nova Vida, antes de se deslocar para o Brasil. 
Em 1958, o missionário Robert McAlister aceitou o convite de um rádioevangelista estadunidense, Pastor Lester Sumrrall para realizar uma cruzada evangelística no Maracanãzinho, no Rio de Janeiro. Era o tempo das cruzadas evangélicas, das tendas de curas e milagres, já inauguradas no Brasil, com sucesso, pela Igreja do Evangelho Quadrangular, também pentecostal e interessada no potencial de fiéis brasileiros. Em um país onde a carência de médicos e políticas de saúde pública, ainda atualmente não foram equacionadas devidamente, a cura divina para os males do corpo e da alma era um atrativo assaz sedutor para as camadas médias e trabalhadores em geral.

O campo religioso brasileiro no final da década de 1950 era constituído por uma rica diversidade: majoritariamente pela Igreja Católica, com a presença das Religiões de Matriz Africana, do Espiritismo, do Protestantismo histórico, do Anglicanismo, do Luteranismo, além de congregacionais, presbiterianos, metodistas, episcopais e batistas, os quais já estavam presentes desde o século XIX com comunidades consolidadas.

No inicio do século XX, o Pentecostalismo, representado pela Congregação Cristã do Brasil e a Assembleia de Deus, estabeleceu-se oficialmente no Brasil, originando outros grupos pentecostais como Igreja Deus é Amor, Igreja O Brasil para Cristo e Igreja do Evangelho Quadrangular. A presença pentecostal acirraria a realidade tensional, característica do campo religioso conforme Bourdieu (1974). Dois anos após sua primeira visita ao País, Robert Mc Alister já desenvolvia um programa evangelístico no rádio, denominado A Voz da Nova Vida, na Rádio Copacabana, Rio de Janeiro, com audiência garantida pelo quadro Perguntas e Respostas sobre a Cura Divina, que presenteava os ouvintes com um livro do mesmo título escrito por McAlister. A introdução do rádio e posteriormente da TV nas atividades proselitistas nos EUA ocorreram desde a década de 1920. O tradicional auditório das congregações ampliava-se exponencialmente com os ouvintes e telespectadores. A novidade do rádio-pregador McAlister atraiu um público ávido por uma espiritualidade dinâmica, afinada com as novas tecnologias.

O auditório da Associação Brasileira de Imprensa (ABI) no Rio de Janeiro tornou-se pequeno para os ouvintes de McAlister, o qual em 1964 já havia fundado a Igreja Pentecostal Nova Vida, com uma membresia especialmente de classe média. O templo sede da Igreja Nova Vida foi organizado em 1971, no bairro de classe média 
do Botafogo, Rio de Janeiro. Em pesquisas recentes, sociólogos também compartilham da opinião que o perfil da Igreja Nova Vida atende a um público de classe média (MARIANO, 2005, p.52).

O Pastor Roberto tornou-se popular no Rio de Janeiro com suas mensagens de cura e milagres. Abriu um gabinete pastoral que recebia, não apenas os membros da Igreja, mas também pessoas de outras religiões, aconselhando sobre as questões espirituais e problemas pessoais. Deu continuidade aos programas evangelísticos radiofônicos, como o "Café Espiritual, com mensagens de cinco minutos, de meia e meia hora na Rádio Relógio" (ARAUJO, 2007, p. 369). Robert Mc Alister escreveu vários livros sobre doutrinas pentecostais e aspectos da vida cotidiana dos fiéis e investiu na formação dos pastores da Igreja Pentecostal Nova Vida, diferentemente da Assembleia de Deus que priorizava os dons espirituais, em detrimento da formação teológica.

Seguindo a orientação da Missão Canadense, Robert Mc Alister na década de 1970 trabalhou como pastor em Roma e posteriormente nos EUA, o que lhe proporcionou outras experiências missionárias e também de governo eclesiástico. Rememorando as origens metodistas do Pentecostalismo e suas observações sobre a melhor estrutura organizacional, McAlister ponderou que a melhor forma de governo para a Igreja Nova Vida era o episcopalismo, isto é, uma igreja administrada por um bispo e um conselho formado por líderes. Em decorrência desse pensamento, o Pastor Roberto se transformou em Bispo Primaz Roberto McAlister, em 1976.

O Conselho Mundial de Igrejas foi organizado em 1948, logo após a Segunda Guerra com uma proposta ecumênica e inclusiva. A Igreja Assembleia de Deus recusou a participar oficialmente do Conselho. No entanto, outros grupos pentecostais como a Igreja Pentecostal o Brasil para Cristo, liderada por Manoel de Mello, nas suas primeiras décadas de existência participou ativamente do órgão ecumênico, inclusive da Coordenadoria Ecumênica de Serviço, sediada em Salvador (COUTO, FERREIRA, SILVA, 2013). Robert McAlister era um homem afeito ao diálogo inter-religioso e entendeu o papel do Conselho Mundial de Igrejas compondo o seu Comitê de Espiritualidade. ${ }^{5}$

O Protestantismo já nasceu plural, dividido em distintos grupos. A Igreja Nova Vida fundada pelo Pastor Robert Mc Alister, também seguiu uma tendência de 
crescimento por cissiparidade, que se observa no Protestantismo internacional e também no Brasil. Divisões e dissidências, que ocorreram por razões doutrinárias, administrativas ou disputas de poder entre lideranças e formas diversas de interpretar o principio do sacerdócio universal de todo cristão, que estabelece que cada fiel pode relacionar e chegar diretamente a Deus, sem a intervenção do clérigo ou da igreja. (SILVA, 1982).

Em 1993, faleceu o missionário Robert McAlister e assumiu a liderança da Igreja Pentecostal de Nova Vida, seu filho Walter Robert McAlister Jr. Um grupo de membros dirigidos pelo Bispo Tito Alencar, descontente com a liderança do Bispo Walter McAlister Jr., saiu da Igreja Pentecostal Nova Vida e fundou a Igreja da Nova Vida. Após arranjos internos decidiram fundar a Denominação Aliança das Igrejas Pentecostais Nova Vida “preservando a cooperação, transparência financeira, as doutrinas básicas e a autoridade episcopal" (ARAUJO, 2007, p.369).

A Igreja Nova Vida expandiu-se pelo território nacional, com campanhas de cura divina e milagres espirituais. Conta, atualmente, com vários templos em São Paulo, Minas Gerais, Bahia, Espirito Santo, Mato Grosso, Rio Grande do Norte e outras localidades interioranas do País. Em 2002 calculava-se a sua membresia em 40.000 fiéis batizados (ARAÙJO, 2007, p. 370).

\section{A expansão pentecostal no Brasil: o Espírito Santo entre Orixás, Guias e Espíritos}

O sociólogo René Ribeiro em suas pesquisas sobre o crescimento do Pentecostalismo no Brasil na década de 1960 sustentou uma tese instigante: que havia um continuum entre a religiosidade mágica de origem afrodescendente, o catolicismo popular e os rituais e doutrinas pentecostais. Segundo Ribeiro, que investigou o desenvolvimento das doutrinas pentecostais em Pernambuco, “o Pentecostalismo aceita a glossolalia e a possessão pelo Espírito Santo e nisso atrai membros dos cultos afro-brasileiros e do espiritismo" (RIBEIRO, 1962, p.16).

A coexistência com uma nebulosa de crenças mágicas e na familiaridade com o mundo dos seres diáfanos, dos Caboclos, dos Pretos Velhos e dos Orixás, convivendo com o transe pentecostal é, igualmente, defendida por Gilberto Velho. Este autor analisa esta familiaridade, a partir da compreensão dos próprios nexos culturais do fenômeno 
religioso. Em outras palavras, sua análise não se centra em variáveis externas ao fenômeno religioso, como classe, escolaridade, etnia, mas na sua própria intelecção; a partir do que lhe é intrínseco. É assim que Velho compreende um "idioma” comum na cultura brasileira, capaz de diluir fronteiras racionais e apostar na convivência possível entre universo mágico, mensagem bíblica e transe, no Pentecostalismo e nas manifestações de Orixás e Espíritos.

Transe, possessão e mediunidade são fenômenos religiosos recorrente na sociedade brasileira. No candomblé, na umbanda, no espiritismo, nopentecostalismo e em outros grupos religiosos, entidades, espíritos, guias, o Espírito Santo, orixás descem ou sobem, se incorporam, se comunicam etc. através de cavalos, aparelhos, ou do que costumamos denominar de indivíduo agente empírico, unidade significativa da sociedade ocidental moderna nos termos de Louis Dumont (VELHO, 1991, p. 124).

Um indício desta coabitação do imaginário popular brasileiro, entre o transe pentecostal, o espírita e o típico das religiões de matriz africana, temos nas memórias de um dos pioneiros do Pentecostalismo no Brasil o sueco, Gunnar Vingren, copiladas pelo seu filho Ivar. Nesta narrativa, há um relato ocorrido no Pará, em 1913, segundo o qual um jornalista foi até a um culto para averiguar os boatos circulantes, de manifestações de espíritos dos mortos, como no Espiritismo, nas reuniões pentecostais. Segundo Vingren, o jornalista chega à conclusão de que há “apenas manifestações do Espírito Santo. Não têm nenhum contato com os espíritos de falecidos" (VINGREN, 2001, p. 65).

O fenômeno, não restrito ao norte brasileiro do início do século XX, evidencia o consumo "de repertórios religiosos afro-brasileiros e neopentecostais", sendo consequência “do papel que as mediações mágicas e a experiência do transe religioso ocupam na própria dinâmica do sistema neopentecostal" (SILVA, 2007, p. 208). Compreende-se assim o esforço de McAlister por compreender o universo umbandista, candomblecista e espírita, a fim de enfrentá-lo a partir da exegese bíblica da qual era portador.

Originário de um país de cultura anglófila e francófila, tradicionalmente cristão, o Bispo Robert McAlister tentou entender a cultura brasileira com o objetivo de "salvar" o país. A população latina e majoritariamente afro-católica e seguidora de "devoções idólatras" causava estranheza ao missionário pentecostal. O pastor canadense seguia 
fielmente as concepções dos protestantes históricos, os quais de forma etnocêntrica desqualificavam os aportes culturais africanos. É assim que McAlister escrevia encontrar um Brasil imerso na superstição católica, espírita e afro-brasileira. Neste sentido, o pastor usa a expressão "tempos medievais" reportando-se a uma visão segundo a qual a Idade Média foi mil anos de obscurantismo da Igreja Católica e da Inquisição, pensamento difundido pela Reforma Protestante, bem como pelo Renascimento (SILVA, 2007).

Concordamos com Rubem Alves a respeito da conversão como a "adesão a um novo discurso", especialmente no universo protestante, como uma experiência de ruptura de antigas práticas, representações e discursos. No entanto, os novos convertidos precisam fazer assimilações e acomodações entre o seu eu anterior e o eu atual, convertido a uma nova fé.

Mesmo sendo tão exclusivistas e ciosas de suas doutrinas, nas comunidades protestantes observam-se pessoas que se converteram, mas persistiram com antigas práticas religiosas, sobrevivências de pertenças religiosas anteriores. Entre os Batistas Independentes na Bahia, grupo majoritariamente formado por pessoas negras, observamos que alguns membros foram eliminados da congregação pelo fato de continuarem a frequentar a Irmandade do Rosário dos Pretos e cultuar "ídolos". (SILVA, 2017).

A mensagem do Bispo McAlister encontrou terreno fértil, também na população de seguidores das Religiões de Matriz Africana e seu investimento evangelístico rendeu bons frutos, a exemplo da conversão da Ialorixá Georgina Aragão dos Santos Franco ao Pentecostalismo. A conversão de uma Ialorixá ao Pentecostalismo era um grande trunfo que alimentava o proselitismo pentecostal e de outras denominações, que transformavam o novo convertido em verdadeiro objeto de propaganda e divulgação de suas respectivas comunidades religiosas, com grande repercussão na mídia. Por outro lado, o investimento religioso de McAlister integrava as lutas para reverter a tradicional identidade católica brasileira como “óbvia”. Um exemplo disso são os discursos, tanto do Pentecostalismo quanto da Umbanda, no sentido de desconstruírem a "obviedade" de um Brasil católico (ISAIA, 2014).

Lizandra Santana Silva estudando o trânsito religioso entre seguidores do Candomblé e das Igrejas Neopentecostais em Cachoeira, Bahia, concluiu que a conversão 
ao Protestantismo de filhas e filhos de santo e Ialorixás e Babalorixás serviam como peças de propaganda dos grupos religiosos envolvidos. Constatou ainda, que alguns convertidos retornavam aos Terreiros de Candomblé alegando obrigação com os seus Orixás, doenças e castigos advindos do abandono de seus guias religiosos. (SILVA, 2014). No livro do Pastor Roberto, a senhora Georgina Aragão dos Santos Franco faz um relato semelhante.

Robert McAlister investiu fortemente na conversão do povo de santo às doutrinas pentecostais, por acreditar que o Candomblé e a Umbanda eram “pragas diabólicas”, com as quais o Catolicismo era conivente (McALISTER, 1968, p.13). Assim, o livro Mãe de Santo foi dedicado "às vítimas do Candomblé e Umbanda" (McALISTER, 1968, p.13 ).

O Bispo pentecostal tentou explicar aos leitores as origens das Religiões de Matriz Africanas e admitia que "oficialmente o Candomblé começou na Casa Branca na Bahia, com três africanas". Denominava o Terreiro como "um ambiente confuso carregado de mistificadores e charlatães” (McALISTER, 1968, p.19). Prossegue o Pastor pentecostal sua narrativa afirmando que "o Candomblé e a Umbanda vieram para o Brasil no coração dos escravos" (McALISTER, 1968, p.13). Ao descrever as nações do Candomblé McAlister expressou de forma clara seu etnocentrismo: “A nação Angola fala da parte da África de onde veio certa forma de Candomblé... Esta é a 'nação' menos civilizada" ( McALISTER, 1968, p.19).

Ao estudar o Pentecostalismo em uma comunidade Quilombola do Ribeirão Grande, interior de São Paulo, Eden Abumansur concluiu que os laços identitários de uma comunidade negra de origem quilombola não foram rompidos, chegando a uma constatação semelhante ao que Ribeiro defendia: “as divisões por razões religiosas não se sobrepõem à unidade identitária do grupo, antes de serem pentecostais esses crentes são quilombolas" (ABUMANSUR, 2011, p. 412).

O Protestantismo no Brasil tem crescido aceleradamente nas últimas décadas, graças à expansão do Pentecostalismo, que além de atingir trabalhadores afrodescendentes, também atrai setores da classe média. Em Oliveira (2004) há a defesa da face predominantemente negra do Pentecostalismo brasileiro. A racionalidade do Protestantismo histórico dificultou a penetração em camadas mais populares afeitas a uma religiosidade emotiva e santorial. O Pentecostalismo, desde as suas origens 
estadunidenses, manteve a "capacidade de conciliar e garantir a convivência pacífica entre elementos mágicos e racionais”(ABUMANSUR, 2011, p.413).

\section{McAlister como antecessor do neopentecostalismo brasileiro}

As disputas de poder ocorrem nos grupos religiosos, com aspectos bastante peculiares, que transitam desde a autoridade de lideranças até as práticas de doutrinas e rituais típicos das agências religiosas. As denominações protestantes, onde não há a sacralidade da figura do sacerdote, pois todos os fiéis são sacerdotes, se relacionam diretamente com a divindade; o que entra na disputa é o próprio carisma do fiel e a demonstração de sua eficácia no interior da comunidade religiosa. Mesmo tendo um governo eclesiástico episcopal na Igreja Pentecostal Nova Vida, havia o exercício sacerdotal entre os leigos, seguindo um caro principio da Reforma Protestante.

O Bispo Edir Macedo, fundador da Igreja Universal do Reino de Deus, converteuse na Igreja de Vida Nova, sob a liderança do Bispo Robert McAlister e não permaneceu na referida comunidade porque queria ser muito mais que um fiel congregado; desejava o pastorado, a liderança religiosa com métodos evangelísticos mais arrojados, frequentemente rejeitados pela autoridade episcopal. Segundo Macedo:

Na Nova Vida, não me consideravam com unção nem para abrir a e fechar as portas na hora dos cultos. Fiquei um tempo imenso, para mim uma eternidade, aguardando uma chance. Onze anos depois, me convenci de que não podia mais esperar. Era hora de dar uma virada (MACEDO, 1984, p.5).

A virada culminou com mais uma dissidência no interior da Igreja Nova Vida protagonizada por Macedo, juntamente com o cunhado Romildo Soares: a fundação da Igreja Universal do Reino de Deus, sob a liderança dos dois, o que não durou muito tempo (ao que parece, ambos tinham a mesma avidez de poder eclesiástico). Romildo Soares separou-se e fundou a Igreja Internacional da Graça, com perfil doutrinário e práticas midiáticas semelhantes aos desenvolvidos pelo Bispo Robert McAlister, antigo mentor espiritual de ambos os pastores.

Justificando a fundação da Igreja Universal do Reino de Deus como um plano divino, o Bispo Macedo declarou: "Por obra do Espírito Santo, nossa igreja foi levantada 
para um trabalho especial, que se salienta em todas as nossas reuniões, a libertação de pessoas endemoniadas" (MACEDO, 1984, p. 16). Na disputa pelos fiéis, o Bispo Macedo desqualificou as Religiões de Matriz Africanas, vistas como práticas diabólicas e condenáveis. Em 1984 o Bispo Edir Macedo publicou pela Gráfica Universal Orixás Caboclos e Guias santos ou Demônios, com clara influência do livro escrito pelo Bispo Robert McAlister em 1968. Tal qual o seu antigo pastor, Macedo também dedicou seu livro “a todos os pais -de- santo e mães- de- santo de nossa pátria” (MACEDO, 1984, p. 6).

A folclorização das Religiões de Matriz Africanas foi e ainda é uma prática recorrente na sociedade brasileira e o canadense. McAlister deve ter ouvido e lido sobre tal processo de desqualificação. Em seu livro registrou: “assim, pois, comecei a enfrentar essa monstruosidade considerada apenas crença folclórica e comecei a usar o poder do Nome de Jesus em oração para libertar os oprimidos desses caboclos e orixás.” Estes são vistos como nada mais "que espíritos malignos e demoníacos.” (McALISTER 1968, p. 12). Em seu livro o Bispo Macedo se reporta as divindades de Matriz Africanas com a mesma desqualificação:

Houve, com o decorrer dos séculos, um sincretismo religioso, ou seja, uma mistura curiosa e diabólica de mitologia africana, indígena brasileira, espiritismo e cristianismo que criou ou fortaleceu o desenvolvimento dos cultos fetichistas como a umbanda, a quimbanda e o candomblé (MACEDO, 1984, p. 19).

\section{McAlister e o Brasil como território de missão: a nomeação do inimigo na narrativa de uma convertida}

A história de Georgina Aragão dos Santos Franco aparece no livro como um exemplo do que McAlister pensava ser os grandes males vivenciados pelo povo brasileiro: o Candomblé, o Espiritismo e a Umbanda. Contudo, já no início da obra, o autor mostra que os julgados responsáveis pelos males físicos, psíquicos e religiosos padecidos pelo povo brasileiro não estavam restritos às religiões afro-brasileiras. Para McAlister, se o povo brasileiro sofria de males físicos, psíquicos e religiosos, em grande parte sucumbindo ao domínio arbitrário de dirigentes do Candomblé e da Umbanda, era porque a religião dominante, o Catolicismo, assim o favorecia. Desta forma, a obra 
tem um endereçamento claro: o que chama de superstição do Candomblé e da Umbanda encontrava no Catolicismo um aliado.

A importância da fonte aqui analisada para a compreensão das relações entre o movimento pentecostal e as religiões afro-brasileiras aparece em Silva (2009) ao pontuar a forma como nela se dá o trânsito de certos "termos" usuais na cotidianidade brasileira, como a familiaridade com o transe. É neste sentido que a teologia da cura divina propagada por McAlister integra um processo de ressignificação simbólica, no qual a vitória de Deus age sobre um inimigo familiar às vivencias de fé do povo brasileiro, como a Umbanda e o Candomblé. Para o autor, citando McAlister, os termos centrais do antagonismo entre Deus e o mal aparecem assim postos:

1. Identificação das divindades do panteão afro com o demônio; 2. Libertação pelo poder (maior) do sangue vivo de Jesus (em oposição ao sangue "seco" ou "fétido" da iniciação ou das oferendas); 3. Em consequência da libertação, a conversão.... (SILVA, 2007, p. 210).

O sucesso da nomeação demoníaca das entidades cultuadas nas religiões de matriz africanas e a compreensão igualmente demonizada dos transes acontecidos no Candomblé e na Umbanda, contava a seu favor com a familiaridade fenomênica brasileira com uma realidade na qual eram fluidas as fronteiras entre a consciência do mundo visível e invisível. Neste sentido, a coabitação entre o Pentecostalismo, a Umbanda, o Candomblé e o Espiritismo aparece para Velho (1991), como anteriormente pontuado, a partir da familiaridade brasileira com o transe, encarado como um componente intelectivo das vivências socioculturais e afetivas do povo.

McAlister apresenta o universo sócio-religioso brasileiro como um mosaico no qual as práticas ancestrais africanas e indígenas compunham-se com o Catolicismo, sem contornos definidos. Às práticas julgadas supersticiosas do Candomblé e da Umbanda, somavam-se, para McAlister, a extrema penetração e aceitação do Espiritismo de matriz francesa em solo brasileiro:

Durante centenas de anos tem o povo misturado uma crença à outra, do que resultou uma espécie de crença que realmente desafia qualquer identificação (Refere-se ao Catolicismo e ao Candomblé). Em muitos lugares a doutrina europeia de Alexandre Kardec 
mistura-se à Macumba, embora muitos espíritas neguem qualquer vinculação com Umbanda. Até a doutrina hindu do carma é aceita por parte dos que também invocam o poder dos Exus (McAlister, 1968, p. 18).

Para McAlister, Candomblé, Umbanda, Macumba e Espiritismo constituíam a nebulosa religiosa na qual se moviam os brasileiros na sua ânsia pelo sagrado; nebulosa esta favorecida pela ascendência religiosa do Catolicismo. Este era encarado, tanto como incapaz de neutralizar os efeitos julgados deletérios desta nebulosa, quanto intrinsecamente eivado de práticas dela favorecedora. Por outro lado, a Igreja Católica aparece na obra como abrindo caminho para a ação da "mão do diabo":

O povo precisava de ajuda para resolver os seus problemas e a Igreja falhou. $\mathrm{O}$ povo precisava de cura e a Igreja lha negou. $\mathrm{O}$ povo precisava de conforto e a Igreja não lho tinha para dar. O povo queria uma crença que lhe satisfizesse a sede e fome de ver alguma coisa real e a Igreja só teve para o alimentar palavrório vazio e não o poder transformador do Evangelho. Sim, à Igreja cabe levar grande parte da culpa pelo crescimento fantástico do espiritismo no Brasil. Mas acima de tudo isso, eu vejo uma conspiração satânica a oprimir milhões de pessoas com os poderes do inferno. Depois de falar com centenas delas, vítimas dessas forças malignas, eu vejo em tudo isso a mão do diabo que ainda hoje vem para roubar, matar e destruir a humanidade (McALISTER, 1968, p. 15).

Ao levantar a voz a respeito da culpa católica frente ao que julgava ser a ação diabólica sobre a sociedade brasileira, McAlister credenciava a sua ação missionária, como solução para a retirada da população do domínio da superstição e da subserviência ao maligno. O Brasil aparecia em sua narrativa como um lugar de missão, entregue ao barbarismo africano. Este, para McAlister, essencialmente ligado a práticas de magia negra e ao culto diabólico. Neste sentido, já no início da obra McAlister deixa claro a partir de que olhar está lendo a realidade brasileira, interpretando seu universo simbólico e compreendendo seu complexo axiológico:

Vindo do Canadá, país predominantemente evangélico, ouvi falar das artes da magia negra e considerei ser aquilo algo dos tempos medievais ou das selvas africanas; portanto nunca acreditei nos poderes atribuídos aos feiticeiros. Chegando ao Brasil tomei conhecimento da crença, popularmente chamada macumba e achei muito interessante este aspecto folclórico do povo brasileiro. As 
coisas que li nos livros de Jorge Amado e as narrativas que ouvi sobre acontecimentos estranhos, julguei-as apenas fruto da superstição, mas nunca dei muita importância a algo tão impossível como seja a influência real da feitiçaria, hoje, no século vinte. Durante os primeiros anos que passei no Brasil falei com literalmente milhares de pessoas, pois abri um gabinete pastoral (...) Dia após dia ouvia narrativas que para mim pareciam duma outra época, até que finalmente fui forçado a considerar seriamente o que estava acontecendo no meio do espiritismo brasileiro (McALISTER, 1968, p. 12).

É sob o filtro de uma formação, na qual a realidade é decodificada a partir da exegese bíblica pentecostal, que McAlister lia a realidade brasileira. Neste sentido, a demonização das religiões afro-brasileiras aparecia como leitura aproximativa da realidade simbólica e axiológica do povo brasileiro com a exegese bíblica na qual foi formado e socializado. $\mathrm{O}$ ponto de vista de McAlister sobre as religiões afro-brasileiras parecia próximo ao discurso do protestantismo pentecostal no Haiti frente às práticas do Vodu, observadas por Alfred Métraux. Segundo o antropólogo suíço, ao contrário do Catolicismo que negava qualquer eficácia nessas práticas, os protestantes reconheciam o poder do Vodu, contra as quais acenavam com o antídoto eficaz da palavra de Deus por eles pregada (Métraux, 1977). Endossando o discurso institucional, a campanha católica contra as religiões afro-brasileiras, capitaneada à época pelo frei Boaventura Kloppenburg, negava qualquer possibilidade e poder nas práticas das religiões afro-brasileiras. Inclusive, à medida que o século XX avançava, Kloppenburg cada vez mais remetia ao discurso médico-psiquiátrico o que anteriormente era creditado à ação demoníaca (ISAIA, 2001). Neste sentido, as palavras de Kloppenburg são suficientemente claras:

O homem não tem a faculdade ou a possibilidade de provocar por sua própria iniciativa e de modo eficiente uma atuação direta e perceptível do demônio ou de qualquer outro espírito do além. Por isso a magia como tal, a necromancia, o espiritismo e o feitiço são impossíveis e ineficazes (KLOPPENBURG, 1961, p. 159).

Contrariamente ao posicionamento católico revelado por Kloppenburg, McAlister reconhecia que havia a manipulação de forças maléficas na cotidianidade brasileira, representada principalmente por aquilo a que chamava indistintamente de Candomblé, Umbanda, Macumba, Quimbanda, Espiritismo: 


\begin{abstract}
Depois falei com vítimas do Candomblé e Umbanda que me contaram do drama terrível que é submeter-se às influências de exus e orixás. Aos poucos fui me convencendo de que essas coisas não eram apenas imaginárias e, apesar de serem frutos de superstição, seus efeitos eram reais (McALISTER, 1968, p. 12).
\end{abstract}

E é aqui que entra a especificidade do antídoto que apresenta à ação considerada demoníaca das práticas das religiões afro-brasileiras e espíritas. Vendo a religião majoritária da população brasileira, não só como ineficaz para combater essas práticas, mas como corresponsável pelo seu sucesso, o pastor credenciava a sua igreja como o caminho capaz de exitosamente enfrentar esse inimigo, tão disseminado na sociedade brasileira, segundo seu ponto de vista.

Ao defender a conivência católica com o que julgava supersticioso e mágico, McAlister adota uma postura muito próxima dos jogos discursivos estudados por Thomas (1991) a respeito do papel operativo da magia no universo acusatório de anglicanos e puritanos frente às crenças populares e aos católicos na Inglaterra reformada. Por outro lado, ao defender que no Brasil as crenças católicas e afro-ameríndias conviviam sem contornos definidos, desafiando mesmo “qualquer identificação” (McALISTER, 1968, p. 18), o pastor fazia eco à tradição de análises a respeito das crenças brasileiras e que, tributárias de Nina Rodrigues, denunciavam justamente esta indefinição das práticas religiosas brasileiras, remetendo-as para uma "anormalidade", capaz de revelar a "ilusão da catequese" católica no Brasil. Nina Rodrigues lamentava a inexistência do que chamava de uma "uniformidade religiosa", na qual o "monoteísmo europeu" passou a conviver "com o fetichismo africano e a astrolatria do aborígene" (NINA RODRIGUES, 1939$, p. 45$)^{6}$.

\title{
Georgina: dos Orixás à Bíblia. A narrativa de um passado ressignificado
}

A narrativa da conversão de Mãe Georgina à Irmã Georgina por McAlister segue uma cronologia, na qual alguns fatos vão se enquadrando e adquirindo significação, integrando um sentido maior: a vitória de Deus sobre o mal e a libertação de uma criatura da subjugação demoníaca. Isto fica claro no objetivo apresentado por McAlister para escrever sobre Georgina: 
Apresenta aqui a sua história para informar ao mundo sobre a miséria que são essas religiões que prestam culto ao diabo, e também sobre o poder libertador que há no Evangelho (...) Esta é mais uma vitória da Cruz sobre satanás e louvamos a Deus por isto e por essa vida salva e protegida pelo sangue do Senhor Jesus (MCALISTER, 1968, p. 30).

Pelo exposto acima, podemos ver que, tanto quando McAlister fala, quanto quando supostamente a Ialorixá fala (ou seja, tanto nos aspectos da construção biográfica, quanto nos de um relato autobiográfico), temos uma narrativa linear, cujos "fatos" narrados são endereçados para um sentido, um esforço teleológico: a vitória divina sobre as hostes demoníacas, da qual a conversão e posterior atuação missionária de Irmã Georgina são o "atestado". Assim, tanto a narrativa de McAlister, quanto o relato supostamente creditado à ex-sacerdotisa do Candomblé integram as características da ilusão biográfica denunciada por Bourdieu:

Primeiramente, o fato de que a vida constitui um todo, um
conjunto coerente e orientado, que pode e deve ser apreendido
como expressão unitária de uma "intenção" subjetiva e objetiva,
de um projeto: a noção sartriana de "projeto original" somente
coloca de modo explícito o que está implícito nos "já", "desde
então", "desde pequeno" etc. das biografias comuns ou nos
"sempre" ("sempre gostei de música") das "histórias de vida"
(BOURDIEU, 1998, p. 184).

Desta forma, a vida de Georgina Aragão dos Santos Franco é apresentada como a de uma mulher marcada já no nascimento para servir aos Orixás, através da herança espiritual de seus antepassados. A narrativa prossegue com os anos nos quais Georgina, frequentando alternativamente a Umbanda e o Candomblé passa a apresentar uma série de sintomas, que aparecem como "provas" da ação demoníaca sobre esta mulher, devido à sua familiaridade com Orixás, espíritos e magia. Uma sucessão de desgraças se abate sobre a vida de Georgina, as quais culminam com um "câncer no sangue". Esta doença, para a qual os Orixás e espíritos se mostravam inoperantes, vai se confrontar com o poder da Bíblia pregada por McAlister, levando à sua "libertação":

A Bíblia diz que é a misericórdia de Deus que nos traz ao arrependimento. Eu creio nisto. Deus foi muito misericordioso quando me permitiu sofrer de um câncer do sangue, pois foi isso que me levou a ouvir, pela primeira vez na minha vida, a mensagem 
poderosa do Evangelho. Eu morava com uma senhora que sofrera glaucoma. Ela fora radicalmente curada desta doença nas reuniões da Cruzada Nova Vida pelas orações do pastor Roberto (...)Eu ficara arrasadíssima por causa dos trabalhos que tivera de fazer no Candomblé e sofria desta doença no sangue, que durante muitos anos me roubava a energia. Então resolvi ir com ela ao auditório da ABI no Rio de Janeiro para ouvir esse pastor e receber uma oração (McALISTER, 1968, p. 57)

Segundo a narrativa, neste mesmo dia deu-se a conversão de Georgina Aragão dos Santos Franco, à qual vai se seguir um período de divisão entre a aceitação da mensagem bíblica que vivenciara na reunião da Cruzada Nova Vida e as antigas práticas do Candomblé. Ou seja, entre a decisão de seguir a exegese bíblica aprendida com McAlister e as antigas práticas do Candomblé e da Umbanda, integrantes da sua formação cultural. Uma dissociação entre o propósito racionalmente orientado de "seguir a Jesus" e o comportamento mágico-mítico com o qual moldara a sua personalidade e o seu processo de socialização desde a infância. Este conflito intenso, que durou cerca de um ano é narrado em um subcapítulo, sintomaticamente intitulado: “Quartas feiras com Deus e Quintas com o diabo”, referindo-se aos dias nos quais Georgina ouvia a pregação de McAlister e aqueles nos quais reincidia no Candomblé:

Durante um ano inteiro eu não tive forças para deixar de ir fazer os trabalhos do Candomblé, nem de ir aos centros de Macumba e participar dos sacrifícios e trabalhos lá (...) Eu trabalhava em dois terreiros, Candomblé e Umbanda, mas a partir do primeiro dia em que aceitei a Cristo como meu Salvador, quando eu chegava ao centro e quando eu via esse povo em transe, recebendo aqueles Caboclos ou Orixás, já não suportava mais aquilo e sempre dava desculpa de estar doente para não participar. Apesar de não estar completamente livre do poder do diabo, eu não podia mais me submeter a essas coisas. Não suportava mais aquele ambiente (McALISTER, 1968, p. 59).

Por outro lado, a narrativa da conversão de Georgina à Cruzada Nova vida segue as características típicas do processo de conversão cristã. Neste sentido, autores como Christian Décobert insistem nos aspectos narrativos da conversão cristã, enfocando-as como "cenografias de um drama" (DÉCOBERT, 2001). Nessas narrativas, o passado, a herança cultural, a memória ancestral, precisam sofrer um corte para que a aceitação ao evangelho possa ser significativa e includente para o novo cristão. Para Décobert, o 
paradigma narrativo de conversão cristã generalizou-se no ocidente a partir dos séculos IV e V, como histórias daqueles que rompiam com o passado, encarando o Cristianismo como uma superação do mal, da heresia, da mentira. Nesta superação, o caminho para o pertencimento à Igreja era fundamental para marcar a passagem da sujeição não racional à tradição e aos costumes pagãos, para a aceitação racional e volitiva do que se considera como verdade do Cristianismo. Neste processo, a partir da conversão de Georgina, todas as antigas práticas mágicas, bem como o contato com os deuses africanos e com os espíritos da Umbanda passam a ser vistos sob a ótica simultânea do pecado e dos comportamentos desviantes. O Cristianismo, encarado como a sacralização da norma social, passa a significar de maneira totalizante a existência; já os antigos comportamentos, práticas e crenças passam a ser vistos como "ao mesmo tempo anômicos e como empecilhos à integração ao grupo portador de valores sagrados; como comportamentos que levam à marginalidade social" (DÉCOBERT, 2001, p. 70).

\section{Concluindo}

As reflexões de Décobert acenam para a compreensão do drama íntimo de Georgina, para a situação liminar que sofreu ao pensar-se racionalmente convertida e, ao mesmo tempo, ligada afetiva e simbolicamente aos Orixás e Espíritos. O discurso da conversão que aprendia na Cruzada Nova Vida não operava com negociações possíveis com a antiga ordem gnoseológica e axiológica na qual a Georgina, Ialorixá, se movia. Com o Pastor McAlister, Georgina aprendia que o Candomblé e a Umbanda integravam a luta travada pelo espírito maligno para perder definitivamente as almas. Apenas a conversão incondicional à palavra de Deus livraria, sem qualquer negociação possível, candomblecistas, umbandistas e espíritas do domínio do maligno. A conversão total de Georgina aconteceria no momento em que ressignificasse completamente as antigas práticas através da ótica judaico-cristã dominante, segundo as quais o seu passado era visto como o domínio demoníaco sobre todos os aspectos da sua vida. É neste processo de ressignificação simbólica que as práticas ancestrais africanas adquirem outro nexo de inteligibilidade. Um exemplo disso está na nova compreensão demonizada do Orixá Exu, a qual Georgina passa a endossar, a partir da sua conversão. Sabe-se que a representação 
demonizada do Exu tem explicação, sobretudo a partir do olhar dos missionários católicos e protestantes no continente Africano (PRANDI, 2005), generalizando-se no Brasil do pós-abolição em um processo que tem a ver com o esvanecimento da memória ancestral africana e com a integração dos negros ao mercado de trabalho urbano (BASTIDE, 1971; ORTIZ, 1991). Como a narrativa de McAlister segue uma ótica negadora de qualquer diálogo compreensível com a cultura africana e brasileira, obviamente não é capaz de captar o outro lado da imposição simbólica que leva adiante, capaz de simplesmente demonizar o que se movia por uma lógica completamente distinta do binarismo judaicocristão. Este outro lado estava marcado pelo que aparece em Herkovits (1992), tanto como a reinterpretação dos ensinamentos católicos quanto da pregação protestante (adquirindo aqui, principalmente, a ação do Espírito Santo, um claro ponto aproximativo com o transe, completamente familiar ao seu universo cultural). Sobre a plasticidade da ressignificação africana, Herskovits a estende a outros complexos culturais e religiosos, como o muçulmano, conforme o exemplo que cita, referente aos haussá da Nigéria setentrional (Herkovits, 1967). Da mesma forma, Métraux (1977) analisava o sucesso da ação missionária protestante no Haiti frente ao Vodu, a partir justamente da compreensão do universo cultural pré-existente.

Compreende-se assim o drama íntimo de Georgina Aragão dos Santos Franco. O que aparece no livro como um período de coexistência entre Deus e os demônios, a partir da lógica de uma narrativa cristã de conversão (DÉCOBERT, 2001), é aqui visto como um processo no qual a aparente ruptura com o passado, na verdade ressignificava o antigo repertório mágico-mítico presente no Candomblé e na Umbanda. Processo doído, marcado por oscilações, as quais antes de afirmar um binarismo lógico e linear, afirmavam o que Velho (1991) defendeu como articulações possíveis e necessariamente compreensíveis de um mesmo "sistema cultural".

\section{Referências}

ALVES, Rubem. Protestantismo e Repressão. São Paulo: Edições Loyola, 2005.

ARAÚJO, Isael. Dicionário Movimento Pentecostal. Rio de Janeiro: CPAD, 2007.

BASTIDE, Roger. As religiões africanas no Brasil. São Paulo: Livraria Pioneira, 1971. 
BOURDIEU, Pierre. A economia das trocas simbólicas. São Paulo: Perspectiva, 2007.

. A ilusão biográfica. In: FERREIRA, Marieta de Moraes; AMADO, Janaina. Usos e abusos da história oral. Rio de Janeiro: FGV, 1998.

COUTO, Edilece; FERREIRA, Muniz; SILVA, Elizete da. Ecumenismo e Cidadania. A trajetória da Coordenadoria Ecumênica de Serviços. In MOURA, Lucyvanda. São Leopoldo: CEBI, 2013.

D EPINAY, Christian Lalive. O Refúgio das Massas. Estudo Sociológico do Protestantismo no Chile. Rio de Janeiro: Paz e Terra, 1970.

DÉCOBERT, Christian. Conversion, tradition, institution. Archives des Sciences Sociales des Religions, n. 116, pp. 67-90, 2001.

HERSKOVITS, Meville. Pesquisas etnológicas na Bahia. Afro-Ásia, n. 4-5, p. 89-106, 1967. . El hombre y sus obras: la ciência de la antropologia cultural. México: Fondo de Cultura Económica, 1998.

ISAIA, Artur Cesar. Hierarquia católica e religiões mediúnicas no Brasil da primeira metade do século XX. Revista de Ciências Humanas, n. 30, p. 67-80, 2001.

. Brasil: três projetos de identidade religiosa. In: Rodrigues, Cristina Carneiro; Luca, Tania Regina de; Guimarães, Valéria. Identidades brasileiras: composições e recomposições. São Paulo: UNESP, 2014.

KLOPPENBURG, Boaventura. A Umbanda no Brasil. Orientação para os católicos. Petrópolis: Vozes, 1961.

LE GOFF, Jacques. História e Memória. Campinas: UNICAMP, 1990.

McALISTER, Robert. Mãe de Santo. Rio de Janeiro: Empreendimentos Evangélicos, 1968.

MACEDO, Edir. Orixás, Caboclos e Guias. Santos ou Demônios. Rio de Janeiro: Universal, 1984.

MARIANO, Ricardo. Neopentecostais Sociologia do Novo Pentecostalismo no Brasil. São Paulo: Loyola, 2005.

MARTIN, David. Tongues Fire. The Explosion of Protestantism in Latin América. Cambridge Massachussets: Blawell, 1989.

MÉTRAUX, Alfred. Le vaudou haitien. Paris: Gallimard, 1977.

NINA RODRIGUES, Raimundo. As coletividades anormais. Rio de Janeiro: Civilização Brasileira, 1939.

OLIVEIRA, Marcos Davi de. A Religião Mais Negra do Brasil. Porque mais de oito milhões de negros são pentecostais. São Paulo: Mundo Cristão, 2004.

ORTIZ, Renato. A morte branca do feiticeiro negro. Umbanda e sociedade brasileira. São Paulo: Brasiliense, 1991. 
PRANDI, Reginaldo. Segredos guardados. Orixás na alma brasileira. São Paulo: Companhia das Letras, 2005.

RIBEIRO, René. Igrejas e Cultos no Brasil., São Paulo: USP, 1962.

SILVA, Elizete da. A missão Batista Independente: uma alternativa nacional. Dissertação Mestrado em Ciências Sociais. Universidade Federal da Bahia, Salvador, 1982.

. Cidadãos de outra Pátria: anglicanos e Batistas na Bahia. Salvador: Sagga, 2017.

SILVA, Lizandra Santana. Do Axé à Aleluia. Transformações do Campo Religioso Cachoeirano. (1980-2007). Mestrado História Universidade Estadual de Feira de Santana, Feira de Santana, 2014.

SILVA, Vagner Gonçalves da. Neopentecostalismo e religiões afro-brasileiras: significados do ataque aos símbolos da herança religiosa africana no Brasil contemporâneo. Mana, v. 13, n. 1, p. 207-236, 2007.

THOMAS, Keith. Religião e o declínio da magia. São Paulo: Companhia das Letras, 1991.

VELHO, Gilberto.Indivíduo e religião na cultura brasileira. Sistemas cognitivos e sistemas de crença. Novos Estudos, n.31, p. 121-129, 1991

VINGREN, Ivar. Diário do pioneiro. Rio de Janeiro: CPAD, 2001.

\section{Notas}

1 Programa de Pós-Graduação em História, Universidade Federal de Santa Catarina (UFSC), Florianópolis, SC, Brasil. arturci@uol.com.br. Escreveu, pesquisou e analisou as informações referentes às religiões afrobrasileiras, além de revisar o texto final.

2 Programa de Pós-Graduação em História, Universidade Estadual de Feira de Santana (UEFS), Feira de Santana, BA, Brasil. cliosilva@yahoo.com.br. Escreveu e pesquisou e analisou os dados sobre a vida de Robert McAlister, bem como sobre o movimento pentecostal brasileiro, além de revisar o texto final.

3 Como é o caso de Luigi Francescon, que funda a Congregação Cristã do Brasil em 1910.

4 Como é o caso de Gunnar Vingren e Daniel Berg, que fundam a Igreja Evangélica Assembleia de Deus.

5 Convém ressaltar, que o Conselho Mundial de Igrejas estava muito atento ao crescimento do Pentecostalismo na América Latina, inclusive no Brasil. Na década 1960 financiou pesquisas científicas sobre os grupos pentecostais, a exemplo do Refúgio das Massas Estudo Sociológico do Protestantismo no Chile do sociólogo canadense Christhian Lalive D'Epinay, obra que se tornou referência para os estudos acadêmicos sobre o Pentecostalismo.

6 Contudo, McAlister não fazia menção à mestiçagem como fundamento de tal indefinição, como aparecia no pensamento de Nina Rodrigues. 